\title{
CONTESTING RELIGIOUS FAMILY RIGHTS: MUSLIM AND HINDU WOMEN'S LAND OWNERSHIP IN JAVA AND BALI
}

\section{Achmad Fawaid}

Universitas Nurul Jadid, Probolingoo, Jawa Timur, Indonesia

e-mail :fawaidachmad@gmail.com

\section{Busro}

UIN Sunan Gunung Djati, Bandung, Jawa Barat, Indonesia e-mail:busro@uinsgd.ac.id

\author{
Submission: 11 January $2020 \quad$ Revised: 17 February $2020 \quad$ Published: 16 March 2020
}

\begin{abstract}
This article depicts issues of the connection between women's status and their roles in landownership in Java and Bali. In Java, for example, despite the fact that they are fortified by family law, just around one-third of land ownership belongs to women. In Bali, the Hindu women need to comply with the standard law in which they deal with a dilemma between their privileges and their reliability towards their families, networks, and culture. The absence of women's land ownership, either by the customary law or by the land enrollment, shows that the agrarian approach of land enlistment consistently gets women into the lower status of their legal ownership. Additionally, it impacts on the manners in which they practice religious convictions as they are situated in troublesome way of any legal issues, including family law (bukum keluarga) and inheritance rights (bak waris). Not with standing the Javanese government's endeavors to teach the general population about land enrollment and a couple of Hindu families to move a component from parent to little girl through a deed of offer before the land deed official, a few women know about the registration phases and the religious instrument of legacy rights. Subsequently, the manners in which Java and Bali women' inclinations are not bargained in political, social, and religious aspects. This article concludes that formal methodology for the exchange of land ownership when land is sold or partitioned in Bali, and also, standard Javanese practices in which insurance to the possibility of marital goods is given.
\end{abstract}

Keywords: Women, Hindu, Muslim, Land ownership.

\section{Abstrak}

Artikel ini berusaha menjelaskan hubungan antara status wanita dalam konteks agama dan peran mereka dalam kepemilikan tanah di Jawa dan Bali. Di Jawa, misalmya, meskipun kondisi mereka diperkuat oleh bukum keluarga, hanya sepertiga dari sertifikat tanah yang beratasnamakan perempuan. Sebaliknya, perempuan di Bali barus mengikuti bukum adat yang menghadapkan mereka pada dilema antara kebutuban sehari-harinya di saatu sisi dan kepatubannya terbadap keluarga, masyarakat, dan kebudayaan lokal di sisi lain. Minimnya kepemilikan tanah oleh perempuan ini, baik yang disebabkan oleb bukum adat maupun oleb hukum formal, memperlibatkan bahwa kebijakan pertanaban seringkali menempatkan mereka dalam status yang inferior. Mereka sama-sama menghadapi kesulitan di badapan bak waris maupun bukum keluarga. Sekalipun di Jawa sudah ada sosialisasi terkait pendaftaran tanab dan di Bali sedikit dari mereka yang memberikan bak kepemilikannya kepada anak perempuannya, mereka tetap saja masib belum banyak memahami prosedur registrasi tersebut dan semakin marjinal dalam kepemilikan tanah dari hak waris. Kondisi ini memperlibatkan bagaimana perempuan Jawa dan Bali tidak terlalu diperbitungkan dalam ranah kebudayaan, politik, dan agama. Artikel ini akbirnya berkesimpulan babwa perlu ada prosedur penjaminan tanah ketika tanah itu dibagikan di Bali, dan perlu ada jaminan keamanan terhadap bak-hak waris dalam adat Jawa.

Kata Kunci: Perempuan, Hindu, Muslim, Kepemilikan tanah

\section{Background}

Generally, women have a small percentage of landownerships in Indonesia ${ }^{1}$.

1 A commonly cited United Nations estimate states that women make up one-half of the world's population and do two-thirds of the labor, but only earn $10 \%$ of the world's income and own only $1 \%$ of the world's property. World Conference of the United
Nations, "Decade for Women, Equality, Development and Peace, 20-21st mtg., at 8, A/CONF.94/35 (1980) (held in Copenhagen, July 14-30, 1980). This, however, is only a rough estimate. Exact figures on the percentage of land owned by women are very rarely tracked by national censuses, creating difficulty to state with any precision how much land women own worldwide. While the exact percentage of land owned by women is unascertainable, it is clear that women own a much 
It impacts on their role in the agricultural machinery of production and their dependence on the livelihoods. Meanwhile, there are incredible benefits possible from having secure rights on land, either to gain income or to make domestic policies. In order to have certain access to government programs, and to increase independent income, women's ownership of land is necessary. Their lack of ownership of land is possible since their role is marginalized in the personal status of the family and informal registration of state $^{2}$. The different situations of their role can be viewed in a different context and background. In Java, for instance, their landownership is strengthened by family law but weakened by land registration, while in Bali the local tradition is to make their role lower than the national law. However, even the situation is different, their status still keeps in marginalized in overall society.

The issue has raised in accordance with their landownership, i.e. why are there are so few women landowners? Some women have a lack of access to domestic incomes, some of them did not have sufficient knowledge on land registration, they themselves simply do not have any ownership interest in the land ownership ${ }^{3}$. This article is to focus on the reasons women had limited access to do belongs to household and landownership in Java and Bali, and the ways they get a dilemmatic position in giving their rights to their husband or to independently organize their own land for production. They need recognition of having landed from traditional or national law in order to strengthen their

smaller fraction of the world's land than men. G. B. Villamor, et al. "Land Use Change and Shifts in Gender Roles in Central Sumatra, Indonesia." International Forestry Review, 17. 4 (2015), p. 65.

2 World Conference of the United Nations.

3 Jennifer Brown, 'Rural Women's Land Rights in Java', Pacific Rim Law \& Policy Journal, 12. 3 (2003), p. 631; cf. A. Lucas, 'Land Disputes in Indonesia: Some Current Perspectives', Indonesia, 53.1 (1992), p. 80. land rights within their household. However, after Suharto's fall in 1989 and rising democratic autonomy in local government, some Balinese authorities utilized their recently discovered opportunity to overlook national laws on equality among women and men. ${ }^{4}$ In Java, despite the fact that Indonesia's Marriage Law gives the insurance of women's property, the customary law of ladies' territory rights is distinctive in practice.

This paper attempts to analyze two important questions. Firstly, how can Javanese women be granted ownership over land that their household already owns? One strategy that the government usually used to ensure women's property rights is through marriage laws that award both a couple of coownership over property obtained during their marriage. However, if a woman's ownership interest in land, as granted in a country's marriage law, is not supported through the country's land law, and more specifically it's land registration law, the ownership rights granted under its marriage law may very well be meaningless. This is because ownership, as granted by legislation, may not be known or understood, especially in rural areas of developing countries. In these settings, the actual name on the title or in the registration records may carry far greater significance in terms of perceptions of ownership.

Secondly, how can Balinese women be granted to have a preserved right for an inheritance? For centuries, only men are preserved right for inheriting due to the patriarchal system. Therefore, in a very surface of analysis, it easily concludes that

${ }^{4}$ Read more details, for instance, Ingris Westendorp, 'Personal Status Law and Women's Right to Equality in Law and in Practice', Journal of Human Rights Practice, 7.1 (2015), p. 430-450; cf. Dendi Muhamad, et al., 'Living Close to Forests Enhances People' s Perception of Ecosystem Services in a Forest-Agricultural Landscape of West Java, Indonesia', Ecosystem Services, 8.1 (2014), p. 200. 
only men are deserved for inheriting and women are obviously discriminated against the rights of the beneficiary. The enlightenment of human rights, as well as the teaching of gender and feminism, have instantly opened some Balinese mind and make them questioning on the strict understanding of granting only men to inherit. ${ }^{5}$ It has driven some social and cultural debates that turned people into a dynamic situation. It is worth acknowledging that academician, Majelis Desa Pakraman (Customary Village Assembly in Bali) ${ }^{6}$ and also court plays a significant role in shifting these progressive concerns. They have tried to enlighten and providing a greater understanding with regard to the effect of customary inheritance law in the Balinese traditional communities.

This article is based on research by using the documentary method and field interviews. To begin with, Indonesian laws and guidelines identifying with women' property rights, including the Mortgage Law (1960), the Basic Agrarian Law (1960), Government Regulation No. 24 "On Land Registration" (1997), the Marriage Law (1974), the General Recommendations and General Comments of the Committee on the Elimination of Discrimination Against Women (CEDAW, 2005, 2011), the Indonesian Civil Code, the Compilation of Islamic Laws (ordered in 1991 and utilized as

5 Anju Malhotra, 'Gender and Changing Generational Relations: Spouse Choice in Indonesia', Demography, 28.4 (1991), p. 570.

${ }^{6}$ Majelis Desa Pakraman is an assembly that coordinates the customary villages in Bali. It has hierarchy structure as follows: The top position is called as Majelis Utama Desa Pakraman that chairing at provincial level; the middle level at regency/municipality is called as Majelis Madya Desa Pakraman; the lower level is what so-called as Majelis Alit Desa Pakraman that coordinates customary villages in the territory of district / sub-regency. A. Dewi, "Potensi Hukum Adat: Peran Majelis Desa Pakraman (MDP) Bali dalam Pembangunan Hukum Nasional," Kertha Patrika, 38.3 (2016), p. 34; cf. Anette Fagertun, 'Labour in Paradise: Gender, Class and Social Mobility in the Informal Tourism Economy of Urban Bali, Indonesia', The Journal of Development Studies, 53.3 (2017), pp. 331-335. the premise of choice in strict courts, which have purview over family law and legacy matters for Muslims in Indonesia), the Decision of the Village Assembly Number 01/KEP/PSM-3/MDP Bali/X/2010 (which decides the Balinese lady will get a portion of the man (purusa) legacy rights after reduced $1 / 3$ for legacy and preservation intrigue), were audited.

We led the field interviews utilizing the Rapid Rural Appraisal technique. The interviewees are not respondents to a questionnaire, yet participants in a semiorganized meeting. We utilized an agenda of issues as a reason for questions, however, didn't really address all inquiries in each meeting and in some cases left from the fundamental inquiries to seek after fascinating, startling, or new data. We haphazardly chose interviewees, with the exception of sexual orientation contemplations. We often talked with a few families in every town visited, either in Java or in Bali. We additionally talked with public accountants and land deed-production authorities ("PPATs"), such as legal advisors, scholars, and NGOs in Malang and Denpasar.

\section{Muslim Women's Landownership in Java}

The island of Java is home to roughly $60 \%$ of Indonesian populace ${ }^{7}$ (120.4 million out of a national populace of 203.4 million) and it is the place in which the majority of the land has been enlisted in Indonesia ${ }^{8}$. Java

${ }^{7} \mathrm{NN}$, "Indonesian Population 203.45 Million: BPS," Jakarta Post, Jan. 5, 2001, available at bttp:/ / www.jakartapost.com (providing statistics from the Central Bureau of Statistics ("BPS").

${ }^{8}$ Anthony Bums, 'Land Registration to Improve Security, Transparency, Governance \& Sustainable Resource Management', reprinted in Comparative Study of Land Administration Systemsindonesia Case Study, 4.22 (2002), p. 20; cf. M. T. Sirait, B. White, \& U. Pradhan, U, 'Land Rights and Land Reform Issues for Effective Natural Resources Management in Indonesia' In Redefining Diversity \& Dynamics of Natural Resources 
is thickly populated, running from 720 individuals for every square kilometer in East Java to 12,685 individuals for every square kilometer in Jakarta'. The vas larger part of individuals in Java (particularly in provincial territories) recognize themselves as Muslim, yet most practice a mix of Islam and customary Javanese convictions ${ }^{10}$. Roughly $10 \%$ of Muslims are 'santris', who practice increasingly exacting values of Islam.

In Java, many of the legal protection of landownership is supported and reinforced by Javanese custom. ${ }^{11}$ The problem is a fact that the marital property system according to the law is different in practice. Not everyone had a clear understanding of the concept of marital property. Article 35 of the 1974 Marriage Law ${ }^{12}$ formally adopts the concept of co-ownership of property purchased during the marriage. This concept is similar to the Javanese concept "gonogini". It also implies a situation that property acquired by gift or inheritance and property purchased prior to marriage are the separate property of the receiving spouse. In Java, what they understand is a fact that the 1974 Marriage Law is a just formalization of the long-used practiced customarily tradition among them. They believe that consensus is a final solution

Management in Asia, Volume 1, (UK: Elsevier, 2017), p. 145.

9 Salahudin Muhidin, The Population of Indonesia: Regional Demographic Scenarios Using A Multiregional Method and Mutiple, Data Sources, ch. 2 (2002) (Population Studies Series). The high density of population on Java is at least partially due to the island's extremely fertile volcanic soil.

10 Overall, Indonesia is about $87 \%$ Muslim, but other religions predominate in some pockets of the country. United Nations, Economic and Social Commission for Asia and The Pacific, Women in Indonesia: A Country Profile 10, U.N. Doc. ST/ESCAP/1767 (1998).

11 L. B. Williams, Development, Demography, and Family Decision-making: The Status of Women in Rural Java. (New York: Routledge, 2019), p. 54.

${ }^{12}$ Departement of Religious Affairs, The Compilation of Islamic Law in Indonesia (1996/1997). of making a major decision on what to do with their separate property ${ }^{13}$.

In the context of Islam, inheritance is administered by Islamic law. Meanwhile, the Civil Code is commonly utilized for the nonMuslim community. The code of "Compilation of Islamic Law" as a legal basis is utilized to make an agreement that Muslims can give up to $33 \%$ of their property by will ${ }^{14}$. The remaining property, or all property in terms of intestacy, is administered under Islamic succession rules. At the point when a wedded individual bites the dust, half of any marital property turns into the different property of the endurance mate, and the other portion of the marital property lapses to their beneficiaries as if it were isolated property per a will or intestacy rules. Not many families adhere to Islamic inheritance rules, rather they follow customary Javanese customs. Almost they follow the Javanese custom of giving all youngsters equivalent portions of a deceased parent's property as opposed to Islamic Law, which gives a bigger offer to children.

In terms of the Marriage Law, marital property must be separated at the period of divorce "as indicated by the individual laws."15. By individual laws, it implies with religious, civil, or common law that oversees the companions. Under Islamic law, every couple has the privilege to get half of the marital property and each one of them holds the privilege to their different property ${ }^{16}$. Likewise, divorced couples are allowed to settle on their own understandings with

${ }^{13} \mathrm{NN}$ (Rural Farmers), Interviews \{Saturday, 23 July 2017$\}$.

${ }^{14}$ There are four types of courts in Indonesia: civil, religious, administrative and military. Mark Cammack, 'Islam, Nationalism, and the State in Suharto's Indonesia', 17 Wis. INT'L L.J. 27.1 (1999), p. $50-51$.

${ }^{15}$ Departement of Religious Affairs, The Compilation of Islamic Law in Indonesia (1996/1997), Ch. VII, art. 37.

${ }^{16} \mathrm{Ch} . \mathrm{XIII}$, arts. 96-97. 
respect to how to divide marital property. Commonly, the divorced Javanese couples move responsibility for property to their children during the period of divorce, regardless of whether they are as yet youthful. If they are without children, they commonly split the marital property in equal manners. Divorced individuals held their different properties.

This lack of registered ownership rights for women can harm their interests in two ways. First, because such women may not recognize themselves as landowners, the benefits of women's land ownership (for example, increased leverage within the household and increased control over family income) will not fully accrue to them. Second, if a woman is not a registered owner, she may be deprived of her land ownership right through a land sale orchestrated by her husband or maybe denied her share of the couple's landholding at the time of divorce or widowhood. A woman might lose her land rights through an unauthorized transfer by her husband because officials overseeing transfers, the transferee, and perhaps even the transferring household itself, may not realize that the wife is a co-owner of the land who must be consulted and give her approval before land can be sold. Similarly, a woman who is not a registered owner may be deprived of her land right at the time of divorce, as her husband may view the land, which is only recorded in his name, as his exclusive possession.

\section{Hindu Women's Landownership in Bali}

The landownership in Bali is particularly intriguing. The women's rights of land are debatable in many developing nations and some advancement has been made ${ }^{17}$. In Bali,

\footnotetext{
${ }^{17}$ Some of them includes B. Agarwal, 'Gender and Land Rights Revisited: Exploring New Prospects via the State, Family, and Market', Journal of Agurarian Change, 3.1-2 (2003), p. 184-224; Kambel, E.R. 'Are Indigenous Rights for Women Too? Gender Equality
}

the circumstance incomprehensibly appears to have moved in reverse instead of forward since the fall of the Suharto system in 1998. Likewise, while (women's) land rights in Bali have been discussed in various settings, for instance of imperialism ${ }^{18}$, the travel industry $^{19}$, agrarian reform ${ }^{20}$, and equality ${ }^{21}$ from sociological, social anthropological, legal, and political point of view, they have not yet been inspected regarding individual law status, in spite of the fact that this causes an average lawful and moral quandary for an expression that is involved with human rights bargains, as the standards of balance and non-separation are inconsistent with customary male patriarchat thoughts, and it makes a bind for ladies who need to pick between reliability to their locale and their individual rights and needs.

In regions where religious and traditional laws are commonly based, such as Bali, the

and Indigenous Rights in the Americas: The Case of Surinam.' In T. Loenen and P. R. Rodrigues (eds), Non-Discrimination Law: Comparative Perspectives (The Hague London Boston: Kluwer International, 1999), p.167-179; Muthoni Wanyeki (ed.), Women and Land in Africa: Culture, Religion and Realizing Women's Rights (London and New York: Zed Books, 2003), p. 20; Zoomers, A., and G. van der Haar (eds). Current Land Policy in Latin America: Regulating Land Tenure under NeoLiberalism (Amsterdam: Royal Tropical Institute, 2000), p. 20.

${ }^{18} \mathrm{M}$. Covarrubias, Island of Bali. Originally published 1937, (New York: Alfred A. Knopf; 1973), p. 23.

${ }^{19}$ Astiti Tjokorda Istri Putra, Anak Agung Istri Ari Atu Dewi, and M. Faure, 'Tourism Development and Customary Land Law in Bali: The Case of the Tenganan Pagringsingan Village', Southwestern Journal of International Law, 20.1 (2013), p. 119-40; cf. J. Cukier, J. Norris, \& G. Wall, 'The Involvement of Women in the Tourism Industry of Bali, Indonesia' The Journal of Development Studies, 33.2 (1996), p. 248-270.

${ }^{20} \mathrm{~A}$. Lucas, and C. Warren (eds), Land for the People: The State and Agrarian Conflict in Indonesia, (Athens, Ohio University Press, 2013), p. 32.

${ }^{21}$ N. Rao, Women's Access to Land: An Asian
Perspective, Accra: UN Women
(EGM/RW/2011/EP.3), 2011; cf. Hanna Christine
Ndun, Sarah Suttor, I Gusti Agung Ayu Dike
Widhiyaastuti, 'Does Customary Law Discriminate
Balinese Women's Inheritance Rights?', Udaya Journal
of Law and Culture, 2.1 (2018), p. 97-114.


discrimination against women in matters of inheritance and their relationship with their husband is still high ${ }^{22}$. The autonomous bureaucratic local government has greatly influenced the ways they decide on Balinese everyday life, including inheritance between women and $\mathrm{men}^{23}$. Since the greatest majority of Balinese are Hindu, the national law of inheritance and land rights seems to get lower impact rather than the local Hindu rules and regulations. Although according to Hindu teaching in the Manawa Dharmasastra (the Hindu holy book) male and female persons are inherent of equal worth, they are supposed to play different roles in society and therefore are entitled to different privileges commensurate with these roles. In line with this matter, the Balinese or Adat laws in respect of family, marriage, and inheritance are not based on equality, but on equity; ${ }^{24}$ a person will have rights and duties that befit his or her gender and status in society. ${ }^{25}$

Article 1 of the Marriage Act recognizes the equality of males and females. Property obtained during the marriage is regarded as joint property and subsequently, both spouses have equivalent rights to manage it and both are qualified for half of it if there

${ }^{22} \mathrm{UN}$ Committee on Economic, Social, and Cultural Rights (CESCR), Combined Sixth and Seventh Periodic Reports of Indonesia, CEDAW/C/IDN/6-7, 2011

${ }^{23}$ P. Windia Wayan, Danda Pacamil, Catatan Popular Istilah Hukum Adat Bali (Notes on Popular Balinese Customary Law), (Denpasar: Upada Sastra, 2004), p. 1.

${ }^{24}$ Equity appears to be positive for women since it is synonymous to fairness, but it is especially used to distribute assets unequally between men and women in correspondence to unequally valued responsibilities. Charlesworth, H., and C. Chinkin, The Boundaries of International Law: A Feminist Analysis (Manchester University Press, 2000), p. 80.

25 A. Fawaid, 'Menuju Etika Pendidikan Kesetaraan: Membendung Bias Gender, Mencari Perspektif Humanis', Musãwa Jurnal Studi Gender dan Islam, 6.1 (2008), p. 57. should be an occurrence of separation ${ }^{26}$. The Balinese law on inheritance that was classified by the Commissioner (Residen) of Bali and Lombok, Frederik Liefrinck in a guideline (Peswara) of 13 October 1900 issued that women, particularly widows, have a marginalized role on it. They are not regarded as independent people, but as individuals who must be dealt with. The estate has no privilege to acquire from her dad in terms of the fact that the overwhelming duty comparable to religious functions, the progenitors, and the sanctuaries must be carried by her brother(s). While young women and ladies additionally have very broad duties which are in some extent disregarded or viewed as less significant. The little girls are qualified for the happiness regarding their folks' property, yet the blessings to the girls must be moderately unassuming since the inheritance of the children ought not to be jeopardized.

Despite the fact that the Basic Agrarian Law No. 5 of 1960, the Human Rights Act, and the Marriage Act No. 1 of 1974 adopts a conventional strategy in regard of equality; everybody is permitted to purchase land, there is no legitimate hindrance banning women from having property rights over land. They did not consider the diverse financial situation of women and in this way did not add to the accomplishment of equality of result. After the self-governing arrangement of decentralization has been controlled, the authorities in Bali guarantee that they don't need to actualize Indonesian national laws in terms of Bali's self-

${ }^{26}$ However, the object and purpose of article 5 of the Women's Convention is encroached upon by article 31(3) of the Marriage Act providing that the husband is to be regarded as the head of the household, while the wife is responsible for the household and raising the children. Cf. UN Committee on Economic, Social, and Cultural Rights (CESCR), Combined Fourth and Fifth Periodic Reports of Indonesia. $\mathrm{CEDAW} / \mathrm{C} / \mathrm{IDN} / 4-5$. 
governance and Hindu individual status ${ }^{27}$. Likewise, it is evident when they did not concern the universal commitment to equality of women and men.

The additional issue is a reality that numerous Balinese don't comprehend that the local interpretation of Adat law (awig-awig) is no longer incongruity with provincial Adat law. It is conceivable to avoid the Adat framework and go legitimately to the District Court. However, it is difficult to go to the District Court. While the District Court ordinarily welcome a representative of the Majelis Desa Pakraman (Assembly of Village Councils) to be available as an expert witness and his recommendation will be considered, the conceivable lawful disappointment in the District Court and the persistent intrigue to a General Court, at that point to the General High Court, and to definite occurrence to the Supreme Court, practically speaking is too long, exorbitant strategy. If women lose their case in the District Court, usually they will need money related intends to take their case any further.

\section{Registration of Women's Marital Property Rights in Java}

The registration of marital property rights, especially land ownership, is under the administration of the National Land Agency (BPN/Badan Pertanahan Nasional). BPN is responsible for registering land rights in Indonesia. The majority of registered parcels, $62 \%$, are located on $\mathrm{Java}^{28}$. Currently, lands are registered in one of two ways:

27 NN (The Legal Office of Bali), Intervien \{Saturday , 22 July 2017\}.

28 Ben White, 'Agroindustry and Contract Farmers in Upland West Java', The Journal of Peasant Studies, 24.3 (1997), p. 125; cf. Ann Stoler, 'Class Structure and Female Autonomy in Rural Java', Signs: Journal of Women in Culture and Society, 3.1 (1977), p. 7489; cf. Rebecca Elmhirst, et al., 'Gender and Generation in Engagements with Oil Palm in East Kalimantan, Indonesia: Insights from Feminist Political Ecology', The Journal of Peasant Studies, 44.6 (2017), pp. 1135-1147. sporadically, in which an individual owner takes the initiative to register his or her land; or systematically, in which BPN maps and registers an entire village.

The system of land enrollment is normally begun with socialization meeting at night when women rarely visit. The inhabitants are invited by BPN to round out enlistment applications and to submit their property rights to an impermanent BPN office set up in the town. The supporting evidence of ownership may incorporate the girik archive (tax receipt), sale and purchase document, a letter of inheritance, or oral declaration from witnesses. The application form demands the solitary name of the candidate followed by a long queue, yet the form doesn't show that it is feasible for the candidate to demand enlistment in more than one name.

To allude the present information of the orderly enlistment program of BPN, just 1.9 million packages, or an expected $3 \%$ of all bundles are enrolled. Just 30\% of title authentications had been given in the names of ladies, $65 \%$ in the names of men, and $5 \%$ in numerous names ${ }^{29}$. The last classification incorporates both married couples enlisting land mutually and siblings enrolling acquired land together. The information 30\% of enlisted land for the sake of women is generally land that she acquired from her family, and in some uncommon cases, land that she bought with her husband ${ }^{30}$.

It means that during the socialization of land registration, it is difficult to find women or couples who understand that they can make land ownership under the couples. It is partly because of the rare attendance of women in the regular evidence meeting, and

29 Brown.; cf. Rachel Silvey, 'Gender Geographies of Activism: Motherhood, Migration, and Labour Protest in West Java, Indonesia', Asian Journal of Social Science, 31.2 (2003), p. 345.

${ }^{30}$ Brown. 
partly of the available singular name in the registration form. The option to register land under both names is not explained to registrants at the socialization meetings to educate the public about the registration process.

The topics are not covered at socialization meetings, it is caused by possible reasons. Some officials are afraid that providing information about the fact that both the husband's and the wife's names can be placed on the land title certificate is not neutral and might influence a couple's decision on how to register their land ${ }^{31}$. Another one is a fact that during drafting the Registration Regulation in establishing registration operation procedures, it seems that little thought was given to how to handle co-owned marital property at the time of registration ${ }^{32}$. Regardless of the availability of co-registration for married couples, many landowners on Java stated that while both husband and wife co-own property purchased during the marriage, because the husband is ultimately the head of the household, it makes sense to register land only in his name ${ }^{33}$.

In most Javanese families, even though the man is customarily the head of the household, decisions related to the marital property are taken by consensus of both spouses. Husbands and wives usually consult with one another before making major decisions on what to do with their separate property $^{34}$. Both spouses generally participate

${ }^{31} \mathrm{NN}$ (BPN Official), Interview \{Friday, 14 August 2017\}.

32 Brown.

${ }^{33} \mathrm{NN}$ (Rural Farmers\}, Interview \{Thuesday, 22 June 2017\}.

${ }^{34}$ Jennifer Brown, and Firliana Purwanti, 'Registration of Land and Women's Land Rights on Java', Seattle: Rural Development Institute, 21.1 (2002), p. 32; cf. Maria Sagrario Floro, and Ranjula Bali Swain, 'Food Security, Gender, and Occupational Choice Among Urban Low-Income Households', World Development, 4.2 (2013), pp. 89-99. in or are aware of farming operations on their land. In small landowning families, both husband and wife tend to work on the land together and there are generally no social restrictions that prohibit Muslim women from leaving their homes to work in the fields. In large landowning families, usually neither the husband nor the wife work in the fields directly; rather, they hire laborer. Most women, even if they themselves do not supervise the field laborer, are aware of when the land is cultivated and of the finances related to the family's farming operations. There is no custom regarding whether a married couple lives closer to the wife or husband's family, although parents tend to be emotionally closer to daughters and that daughters tend to live closer to their parents. Despite the fact that children often live in different villages from their parents, this does not prevent either sons or daughters from inheriting land. ${ }^{35}$

\section{Status of Women's Inheritance Rights in Bali}

The registration of land in Bali is similar to Java, but the difference is a fact that the lack of education or job training and the inability to earn an adequate income or to acquire property by way of inheritance all negatively affect/Hindu women's property rights over land in practice, despite the formal equality that may be found in some laws. In Bali, the BPN will register the owner of lands under the name of men, not because of the rare attendance of women in the registration meeting, but since Hindu women are regarded as having a lower role in everyday life, their equity is no longer entitled to have rights of the land. This situation is also true in Java, but the Adat settlement

35 Incing, Veronika, Willy Tri Hardiyanto, and Sugeng Rusmiwari, 'Kesenjangan Gender (Perempuan) dalam Mendapatkan Pendidikan pada Masyarakat Pedesaan', JISIP: Jurnal Ilmu Sosial dan Ilmu Politik, 2.1 (2015), p. 57 
system in Bali has no ability to give full equality to women in matters of land ownership. ${ }^{36}$

Similarly, as daughters can't acquire from their fathers, widows are barred from acquiring from their husbands. Since a man's relentless property will generally have a place with his family, his home will go to his children, and in their nonappearance to his nephews or other male family members ${ }^{37}$. This implies access to lodging and land, a widow relies either upon her son(s) or on her parents in law. Two widows clarified that they could stay in the family home since one of their children came to live with them. Issues emerge if the parents in law need to utilize the land and lodging for themselves or if the widow doesn't carry on as per cultural standards, suggesting that she is associated with a sentimental association with a man.

The way that women are subject to a man for land and lodging also has ramifications for women who are engaged with a harsh relationship. For local NGOs, aggressive behavior at home is a problematic concern and the essential motivation behind why women need a divorce ${ }^{38}$. In any case, if they have not financial independence, the consequence might be that they become desperate. However, in common law (Adat Perda Bali), women who depended on this

36 Anju Malhotra, 'Gender and The Timing of Marriage: Rural-Urban Differences in Java', Journal of Marriage and the Family, 21. 1 (1997), p. 439; cf. Herien Puspitawati, Paula Faulkner, and Tin Herawati, 'Gender Relations and Subjective Family Well-Being Among Farmer Families: a Comparative Study between Uplands and Lowlands Areas in West Java Province, Indonesia', Journal of Family Sciences, 3.1 (2018), p. 70.

37 Two widows explained that they could remain in the family home because one of their sons came to live with them. NN (Divorcee), Interview \{Thuesday, 20 July 2017$\}$

${ }^{38} \mathrm{NN}$ (Representatives of Komunitas untuk Indonesia yang Adil dan Setara (Indonesian Society for Honesty and Equality, KIAS) and the Indonesian Legal Aid Foundation (ILAF), Interviews \{Friday, 21 July 2017\}. new principle and who petitioned for legal divorce were not granted their offer by the District Courts ${ }^{39}$.

Most of the mothers will expect that they will lose their kids in the event that they seek a legal divorce since according to Adat law, children conceived in wedlock will have a place with their father's family and the court will appoint them to the father, except if they are still little. Regardless of whether a mother gets care of her children, it might be difficult for her to keep up them in perspective on her constrained money related methods and commonly insufficient lodging conditions. A 39-year-old divorced woman clarified that she had just set out to request a divorce from her injured couple since she was persuaded that she would get half of the marital network. In any case, the District Court in Denpasar didn't grant her offer. In spite of the fact that she got new work, her salary is low to the point that she can't bear the cost of a legal advisor to claim. Her exhusband got to care of two of their three kids; she got to care of the most youthful child. She currently leases one room where she lives with her kid since she can't manage the cost of better lodging ${ }^{40}$.

The Impact of Women's Lack of Landownership in Java

Differently, in Java, the absence of women's land ownership inside the enlistment procedure doesn't appear to truly hurt women's property rights. It is an aftereffect of a few components. To begin with, the Javanese tradition depends on the idea of co-responsibility for property and secures the two companions' privileges to marital property paying little mind to how it is enrolled. Regardless of the way that marital

39 Westendorp.; cf. Kieran, Caitlin, et al., 'Examining Gender Inequalities in Land Rights Indicators in Asia', Agricultural Economics, 46.S1 (2015), p. $119-120$

40 NN (Divorcee), Interview \{Thuesday, 20 July 2017). 
property is most usually enrolled in the husband's name alone, the general conclusion is that the name on the title certificate for the marital property isn't a sign that one partner is the sole proprietor of the property.

Both of them feel confident that regardless of whether just one name is on the title certificate, they are proprietors of property bought during the marriage. Families settled on choices in regards to the utilization and removal of marital property by agreement, regardless of the name in which property was held ${ }^{41}$.

However, it is indispensable that formal legal systems, including land certificate of women's name, is to provide protection of the possible dispute among spouses in the future. It is also functional as a safeguard, such as requiring the consent of both spouses at the time of transfer or mortgage, that protect women's interests in marital property, even if the names of both spouses do not appear in the land register or on the land title certificate $^{42}$. PPAT, in this case, has an important role to make sure that the transfer deed or mortgage deed is fairly confirmed between both parties ${ }^{43}$.

The PPAT will compare the date of marriage against the title certificate to determine if the land was purchased during the marriage. If the land was purchased during the marriage, it is marital property. Thus, while the initial registration does not record a wife's ownership interest in the marital property along with her husband's, later checks at the time that land is transferred ensure that a woman is not divested of her land rights without her knowledge and permission. This is also true at the time land is sold and also true at the

${ }^{41} \mathrm{NN}$ (Rural Farmers), Interview \{Thuesday, 22 June 2017\}.

42 NN (PPAT Official), Interview \{Saturday, 13 May 2017\}.

43 Government Regulation No. 37 on Regulation on Land Deed Making Official (1998) time marital property is divided due to death or divorce.

The requirement of spousal consent at the time of transfer acts as a de facto presumption that property is co-owned marital property. The standard deed requires either the spouse's signed consent or proof that the property is not marital property. This clearly protects women's land rights, even though these land rights may not be registered. Furthermore, at the time of death or divorce, women's interest in the co-owned marital property is also protected by a requirement that they must consent to any property distribution that differs from the legally stipulated distribution.

\section{The Impact of Adat Law on Women's Land Inheritance in Bali}

Hindu tradition is based on sonpreference because a son will remain in the family and he bears important responsibilities in respect of religious ceremonies including cremation rites, the most significant ones because of the belief in reincarnation. In the patriarchal systems, the right to inherit belongs to men as the rightful descendant of his father. ${ }^{44}$ The patriarchal system prevented women to own rights on inheriting. The Balinese customary laws prevail in similar rules of inheritance. It embraces the patriarchal principals in its kinship systems. Under the Balinese customary laws, women seem to have no rights to be descendants of his father ${ }^{45}$.

Under the Balinese inheritance law, there are four elements of inheriting play an important role, such as (1) the ancestor, the one who has the rights to inheritance

44 I. B. Astawa, S. Waloeyo, \& J. E. Laing, 'Family Planning in Bali', Studies in Family Planning, 6.4 (1975), p. 92.

${ }^{45}$ Hanna Christine, Sarah Suttor, and I. Gusti Agung Ayu Dike Widhiyaastuti, 'Does Customary Law Discriminate Balinese Women's Inheritance Rights?', Udayana Journal of Law and Culture 2.1 (2018), 97-114. 
property (pendabulu); (2) the inheritance (warisan) ${ }^{46}$ (3) the descendant (keturunan yang mendapat waris); and (4) the heirs (abli waris) ${ }^{47}$.

Because of the custom of female exogamy, a Hindu woman in Bali who marries leaves her own blood relatives to become part of her husband's family who is supposed to take care of her. That is why it is considered wasteful to leave part of the most valuable family assets to a daughter.

In terms of customary law, a child is regarded as the breadwinner who keeps on banning little girls from acquiring area and lodging from their fathers. ${ }^{48}$ Especially rural women still feel that daughters ought not to acquire in light of the fact that they don't have significant obligations. It appears to be astounding since women in Bali, particularly in Karang Asem, who get up at 4 a.m. and go to the market, work at the land, and play out their day by day religious practices of asking

46 In the Balinese inheritance laws, inheritance property comprising: (1) the inheritance itself, such as: undivided inheritance means the inheritance property which has magical and religious values such as Hindu family temple (merajan, sanggah), worship tools (Siwa Karana), family's iconic and magical weapons (keris), etc; and divided inheritance such as rice field farmland, land, and etc; (2) the congenital property, that is a property belongs to the bride or the grooms which are brought to marriage such as known as Jiwa dana, tatadan and akskaya; (3) marriage property, that is a property which has been obtained during the times of marriages (guna kaya); and (4) the community rights such as worship in territory-based community temples (kabyangan tiga), the use of customary cemetery, and performing Hindu ceremonies such as Pitra Yadnya, a ceremony performed for purifying the soul of the passed away family members, which mostly big and absorbing a huge amount of money. See K. Tajeddini, A. H. Walle, \& M. Denisa, "Enterprising women, tourism, and development: The case of Bali," International Journal of Hospitality \& Tourism Administration, 18.2 (2017), p. 199.

47 These four elements contain a different concept of inheritance and have caused the ustomary inheritance law differ to the Indonesian private laws, as the law only measuring some elements of inheriting such as ancestor, inheritance, and the heirs. Hanna

48 Nitish Jha, 'Gender and Decision Making in Balinese Agriculture', American Ethnologist, 31.4 (2004), p. 554. and offering before they start on their family unit or different errands had gone unnoticed.

Similarly, as daughters can't acquire from their fathers, widows are barred from acquiring from their spouses. ${ }^{49}$ Since a man's unfaltering property will usually belong to his family, his bequest will go to his children, and in their nonappearance to his nephews or other male family members. This implies that for access to lodging and land, a widow relies either upon her children or on her parents in law. Issues emerge if the parents in law need to utilize the land and lodging for themselves or if the widow doesn't act as cultural principles, suggesting that she is associated with a sentimental association with a man. At the point when a widow remarries, she will move to the home of her new spouse.

The way that women are subject to a man for land and lodging likewise has consequences for them who are engaged with an abusive relationship. The divorce is an enormous issue and an essential explanation of much abusive behavior at home ${ }^{50}$. In any case, if they have not financial independence, the result might be that they become desperate. Numerous Balinese women have instructed ones who took an interest at the college level, however, it isn't basically useful because of a circumstance that women are in a substandard situation in regards with property rights and their immediate effect on changing Adat law is constrained; they are enormously inferior in any organization ${ }^{51}$.

\section{Conclusions}

Javanese women's land rights are not compromised, despite the fact that land registration in Indonesia does not reinforce and complement marital land rights granted

49 Veronica H. Long, and Sara L. Kindon, 'Gender and Tourism Development in Balinese Villages', Gender, Work and Tourism, (UK: Routledge, 2005), 99-128.

${ }^{50}$ Westendorp

${ }^{51} \mathrm{NN}$ (NGO Representative), Interview \{Saturday, 22 July 2017$\}$. 
to Indonesian women under the Marriage Law. Two factors account for this difference. First, the formal land transfer procedures, which require wives' signed consent or evidence of the land's separate property status, act as a de facto presumption that property belonging to a married person is community property. This is regardless of whether or not the land is registered in both the husband's and the wife's names. Second, Javanese customary practices recognize and protect the concept of marital community property.

Meanwhile, a particular issue in Bali right now is that District Courts usually decline to apply new laws that would be in a woman's kindness. Especially in situations where they are precluded their part of securing the marital network or a portion of the inheritance, the results are critical since the choice may leave them poor and incapable to hold up intrigue with a higher court. The administrator could tackle this issue by presenting a free-of-charge complaint system prompting a survey of a District Court's choice on the off chance that it is affirmed that the law has not been applied effectively.

For Javanese society, a system ensuring that a woman's name appears on ownership documents for community property would be the ideal system, because it would not only protect women's land rights at the time of transfer or divorce but would also ensure that a woman understands that she has a present ownership interest in the land. A land registration system that accurately reflects land rights granted to women in family law legislation will ensure that women's legal ownership interests in their households' land are recognized and protected. Simply declaring women to be landowners of household land in national legislation is not enough. These high-level policy decisions must be reinforced at the ground level through the implementation of appropriate registration systems that effectively communicate to both women and men that women are indeed genuine owners of the land.

Meanwhile, Balinese Adat community need to be shown that their laws and customs are not set in stone and that it is normal to adjust to societal change; it is not endangered when some rules are modified in favor of women's right to equality, and it needs a full support of local NGO and academics who are able to speak the local knowledge and who know the customs visit communities to convince them. The Decision of the Village Assembly Number 01/KEP/PSM-3/MDP Bali/X/2010, dated 15 October 2010 which determines the Balinese woman shall receive half of the man (purusa) inheritance rights after diminished $1 / 3$ for inheritance and conservation interest has to be socialized to the customary community.

\section{References}

\section{Journals}

Agarwal, Bina, 'Gender and Land Rights Revisited: Exploring New Prospects via The State, Family and Market', Journal of Agrarian Change, 3.1-2 (2003), 184-224.

Astawa, Ida Bagus, Soegeng Waloeyo, and John E. Laing, 'Family planning in Bali', Studies in Family Planning, 6(4) (1975), 86-101.

Astiti, Tjokorda Istri Putra, Anak Agung Istri Ari Atu Dewi, and Michael Faure, 'Tourism Development and Customary Land Law in Bali: the Case of the Tenganan Pagringsingan Village', Sw. J. Int'l L. 20.1 (2013), 119.

Brown, Jennifer, and Firliana Purwanti, 'Registration of Land and Women's Land Rights on Java', Seattle: Rural Development Institute, 21.1 (2000), 32.

Brown, Jennifer, 'Rural Women's Land Rights in Java', Pacific Rim Law \& Polic y Journal, 12. 3 (2003), 631. 
Bums, Anthony, 'Land Registration to Improve Security, Transparency, Governance \& Sustainable Resource Management', reprinted in Comparative Study of Land Administration Systemsindonesia Case Study, 4.22 (2000), 20.

Cammack, Mark, 'Islam, Nationalism, and The State in Suharto's Indonesia, Wis. Int'l LJ 17.1 (1999), 27.

Cukier, Judie, Joanne Norris, and Geoffrey Wall, 'The Involvement of Women in The Tourism Industry of Bali, Indonesia', The Journal of Development Studies, 33.2 (1996), 248-270.

Dewi, Anak Agung Istri Ari Atu, 'Potensi Hukum Adat: Peran Majelis Desa Pakraman (MDP) Bali dalam Pembangunan Hukum Nasional', Kertha Patrika, 38.3 (2016), 32-45.

Elmhirst, Rebecca, et al., 'Gender and Generation in Engagements with Oil Palm in East Kalimantan, Indonesia: Insights from Feminist Political Ecology', The Journal of Peasant Studies, 44.6 (2017), 1135-1157.

Fagertun, Anette, 'Labour in Paradise: Gender, Class and Social Mobility in The Informal Tourism Economy of Urban Bali, Indonesia', The Journal of Development Studies, 53.3 (2017), 331-345.

Fawaid, Achmad, 'Menuju Etika Pendidikan Kesetaraan: Membendung Bias Gender, Mencari Perspektif Humanis', Musãwa Jurnal Studi Gender dan Islam, 6.1 (2008), 57-80.

Floro, Maria Sagrario, and Ranjula Bali Swain, 'Food Security, Gender, and Occupational Choice Among Urban Low-Income Households', World Development, 42 (2013), 89-99.

Incing, Veronika, Willy Tri Hardiyanto, and Sugeng Rusmiwari, 'Kesenjangan Gender (Perempuan) dalam Mendapatkan Pendidikan pada Masyarakat Pedesaan', JISIP: Jurnal Ilmu Sosial dan Imu Politik, 2.1 (2015), 56-67.
Jha, Nitish, 'Gender and decision making in Balinese agriculture', American Ethnologist 31.4 (2004), 552-572.

Kieran, Caitlin, et al., 'Examining Gender Inequalities in Land Rights Indicators in Asia', Agricultural Economics, 46.S1 (2015), 119-138.

Lucas, Anton, 'Land Disputes in Indonesia: Some Current Perspectives', Indonesia, 53. 2 (1992), 79-92.

Malhotra, Anju, 'Gender and Changing Generational Relations: Spouse Choice in Indonesia', Demography, 28.4 (1991), 549-570.

Malhotra, Anju, 'Gender and The Timing of Marriage: Rural-Urban Differences in Java', Journal of Marriage and the Family, 32.1 (1997), 434-450.

Muhamad, Dendi, et al., 'Living Close to Forests Enhances People's Perception of Ecosystem Services in a ForestAgricultural Landscape of West Java, Indonesia', Ecosystem Services, 8 (2014), 197-206.

Ndun, Hanna Christine, Sarah Suttor, and I. Gusti Agung Ayu Dike Widhiyaastuti, 'Does Customary Law Discriminate Balinese Women's Inheritance Rights?' Udayana Journal of Law and Culture, 2.1 (2018), 97-114.

Puspitawati, Herien, Paula Faulkner, and Tin Herawati, 'Gender Relations And Subjective Family Well-Being Among Farmer Families: a Comparative Study Between Uplands and Lowlands Areas in West Java Province, Indonesia', Journal of Family Sciences, 3.1 (2018), 53-72.

Silvey, Rachel, 'Gender Geographies of Activism: Motherhood, Migration, and Labour Protest in West Java, Indonesia', Asian Journal of Social Science, 31.2 (2003), 340-363.

Stoler, Ann, 'Class Structure and Female Autonomy in Rural Java', Signs: Journal of Women in Culture and Society, 3.1 (1977), 74-89. 
Tajeddini, Kayhan, Alf H. Walle, and Mela Denisa, 'Enterprising Women, Tourism, and Development: The Case of Bali' International Journal of Hospitality \& Tourism Administration, 18.2 (2017), 195 218.

Villamor, G. B., et al., 'Land Use Change and Shifts in Gender Roles in Central Sumatra, Indonesia' International Forestry Review, 17.4 (2015), 61-75.

Westendorp, Ingrid, 'Personal Status Law and Women's Right to Equality in Law and in Practice: The Case of Land Rights of Balinese Hindu Women', Journal of Human Rights Practice, 7.3 (2015), 430450.

White, Ben, 'Agroindustry and Contract Farmers in Upland West Java', The Journal of Peasant Studies, 24.3 (1997), 100136.

\section{Books and Reports}

Burns, Anthony, 'Land Registration to Improve Security, Transparency, Governance \& Sustainable Resource Management. Comparative Study of Land Administration Systems', World Bank Asia Regional Workshop on Land Policy and Administration working paper, (World Bank, Washington, DC. 2002).

Charlesworth, Hilary, Sam Chaiton, and C. M. Chinkin, The Boundaries of International Law: A Feminist Analysis (UK: Manchester University Press, 2000).

Covarrubias, Miguel. Island of Bali (New York: Tuttle Publishing, 2015).

Departement of Religious Affairs, The Compilation of Islamic Law in Indonesia (Jakarta: Kemenag, 1997).

Kambel, Ellen-Rose, 'Are Indigenous Rights for Women Too? Gender Equality and Indigenous Rights in the Americas: The Case of Surinam', in T. Loenen en P. Rodrigues (red.), Non-Discrimination Law: Comparative Perspectives (The Hague: Kluwer Law International, 1999).
Lucas, Anton, and Carol Warren. Land for The People: The State and Agrarian Conflict in Indonesia (New York: Ohio University Press, 2013).

Long, Veronica H., and Sara L. Kindon, 'Gender and Tourism Development in Balinese Villages', in Gender, Work and Tourism (UK: Routledge, 2005)

Muhidin, Salahudin, "The Population of Indonesia: Regional Demographic Scenarios Using a Multiregional Method and Multiple Data Sources." Ch 2 (2006), 400-402. (Population Studies Series).

Rao, Nitya, "Women's Access to Land: An Asian Perspective." Expert Paper prepared for the UN Group Meeting 'Enabling Rural Women's Economic Empowerment: Institutions, Opportunities and Participation'. Accra, Ghana. 2011.

Sirait, M. T., White, B., \& Pradhan, U., 'Land Rights and Land Reform Issues for Effective Natural Resources Management in Indonesia' (pp. 141-155). In Redefining Diversity \& Dynamics of Natural Resources Management in Asia, Volume 1 (UK: Elsevier, 2017).

UN Committee on Economic, "Social, and Cultural Rights (CESCR)". Combined Sixth and Seventh Periodic Reports of Indonesia, CEDAW/C/IDN/6-7, 2011.

Wanyeki, Lynne Muthoni, ed., Women and Land in Africa: Culture, Religion and Realizing Women's Rights (Cape Town: New Africa Books, 2003).

Williams, L. B., Development, Demography, and Family Decision-Making: The Status of Women in Rural Java (New York: Routledge, 2019).

Windia, Wayan P. Danda Pacamil, Catatan Populer Istilah Hukum Adat Bali (Denpasar: Upada Sastra, 2004).

World Conference of the United Nations Decade for Women, and United Nations, Report of the World Conference of the United Nations Decade for Women: 
Equality, Development and Peace; NN (PPAT Official), Interview \{Saturday, 13 Copenhagen, 14 to 30 July $1980 . \quad$ May 2017\}

World Conference of the United Nations Decade for Women, and United Nations, "Economic and Social Commission for Asia and The Pacific, Women in Indonesia: A Country Profile 10", U.N. Doc. ST/ESCAP/1767 (1998).

NN (Rural Farmers), Interview \{Thuesday, 22 June 2017\}

NN (Rural Farmers), Interview \{Friday, 23 June 2017\}

NN (Divorcee), Interview \{Thuesday, 20 July 2017\}

Zoomers, Annelies, and Gemma van der Haar, Current Land Policy in Latin America: Regulating Land Tenure Under NeoLiberalism (UK: Royal Tropical Institute, KIT Publishers, 2000).

\section{Interview}

NN (BPN Official), Interview \{Friday, 14 Agustust 2017\}

NN (NGO Representative in Bali), Interview \{Saturday, 22 July 2017\}

NN (Legal Office of Bali), Interview \{Saturday, 22 July 2017\}

NN (Two Widows), Interview \{Thursday, 20 July 2017)

NN (Representatives of Komunitas untuk Indonesia yang Adil dan Setara (Indonesian Society for Honesty and Equality, KIAS) and the Indonesian Legal Aid Foundation (ILAF)), Interviews \{ Friday, 21 July 2017).

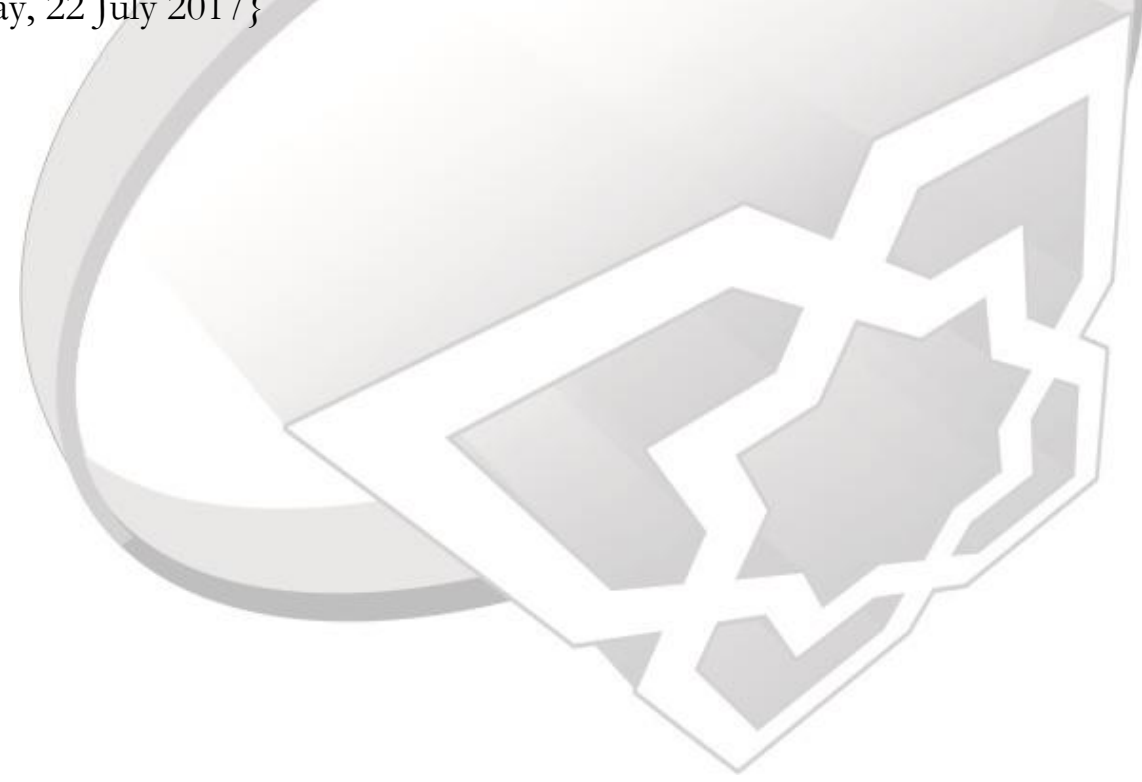

